\title{
PERUBAHAN KARAKTERSIK LAHAN DI KAWASAN STRATEGIS KASIBA-LISIBA TALANG KELAPA KOTA PALEMBANG
}

\author{
Asninda Krisnamutri S., Agam Marsoyo, R. Widodo Dwi Pramono \\ Kanwil BPN Provinsi Sumatera Selatan \\ Jalan POM IX Kampus No. 1296, Lorok Pakjo, Ilir Barat I, Palembang - Telp (0711) 354593 \\ asninda.ks@gmail.com
}

\begin{abstract}
ABSTRAK
Kawasan Siap Bangun (Kasiba)-Lingkungan Siap Bangun (Lisiba) merupakan kawasan strategis dengan keunggulan komparatif berdasarkan permukiman. Pemerintah Kota Palembang menetapkan Kasiba-Lisiba sebagai kawasan strategis sebagai upaya pemerataan pembangunan dan peneyediaan perumukiman. Sebagai sektor penggerak dalam pembangunan wilayah, dampak permukiman sebagai pusat pertumbuhan belum banyak diketahui. Indentifikasi pengaruh penetapan dapat ditunjukkan pada perubahan karakteristik lahan. Tujuan studi ini adalah untuk mengidentifikasi perubahan karakteristik lahan sebelum dan setelah penetapan kawasan strategis di Kasiba-Lisiba Kota Palembang. Metode yang digunakan pada penelitian ini adalah metode deduktif kuantitatif-kualitatif (mix method). Analisa yang digunakan menggunakan analisa deskriptif kuantitatif, analisa before-after, dan analisa tabulasi silang. Hasil analisis menunjukkan berdasarkan lima variabel karakteristik lahan, terdapat empat variabel yang mengalami perubahan yaitu luas lahan terbangun, harga lahan, status lahan, dan pemanfaatan lahan sedangkan satu atribut lahan yang tidak mengalami perubahan antara sebelum dan setelah penetapan Kasiba-Lisiba yaitu cara perolehan lahan. Dengan ditetapkannya Kasiba-Lisiba Talang Kelapa sebagai kawasan cepat tumbuh memiliki pengaruh atau hubungan yang siginifikan terhadap perubahan karakteristik lahan di kawasan.
\end{abstract}

Kata Kunci : karakteristik lahan, Kasiba-Lisiba, pusat pertumbahan.

\section{ABSTRACT}

Kasiba-Lisiba is a strategic area with comparative advantages based on settlements. The government of Palembang City has established Kasiba-Lisiba as a strategic area as an effort to make distribution and development of settlements. As a driving force in the regional development, the impact of settlements as a growth center has not been widely known. Identify the effect of the determination can be shown on the change of land characteristics. The purpose of this study is to identify changes in land characteristics before and after the establishment of strategic areas in Kasiba-Lisiba Palembang City. The method used in this research is a quantitative-qualitative deductive method (mix method). The analysis used quantitative descriptive analysis, before-after analysis, and cross tabulation analysis. The result of the analysis shows that based on five land characteristic variables, there are four variables that have changed namely: built-up area, land price, land title, and land utilization, while one attribute of land that is not changed between before and after Kasiba-Lisiba determination is land tenure. With the establishment of Kasiba-Lisiba Talang Kelapa as a fast-growing area has a significant influence or relationship to the changing land characteristics in the area.

Keywords: land characteristic, kasiba-lisiba, growth pole.

\section{PENDAHULUAN}

Perubahan yang terjadi pada lingkungan sosial, ekonomi, budaya masayarakat akan menimbulkan tekanan penduduk terhadap kebutuhan sumberdaya lahan. Perkembangan kota dan kebijakan pembangunan menjadi salah satu penentu perubahan pada bentuk fisik lahan, aktivitas dan kegiatan masyarakat. Aktivitas masyarakat dan tekanan terhadap permintaan lahan secara tidak langsung akan merubah karakteristik suatu lahan. Lahan akan digunakan pada kegiatan yang paling menguntungkan dan dianggap paling sesuai oleh manusia di atasnya.

Karakteristik lahan sebagai identitas suatu lahan merupakan sesuatu yang dapat diukur dan memiliki ciri yang berbeda dengan lahan yang lain. Perubahan karakteristik lahan dapat terjadi berdasarkan karakteristik fisik lahan, ekonomi lahan, dan fungsi lahan. Perubahan karakteristik mengacu pada suatu pergantian (perbedaan) ciriciri tertentu. Perubahan karakteristik mengandung tiga unsur penting, pertama terdapat perbedaan perwujudan fisik lahan. Kedua konsep 
ciri atau identitas suatu perubahan baik ciri sosial, ekonomi, atau ciri penampilan sesuatu. Ketiga bersifat historis yang terikat pada satuan waktu yang berbeda-beda (Giyarsih, 2012).

Menurut Sadyohutomo (2016) identitas suatu lahan dapat dibagi menjadi: sifat dasar tanah (soil nature), sifat geografis lahan (landform), penggunan lahan (land use), nilai lahan (land value) dan status lahan (land title). Lebih lanjut disebutkan, sifat dasar tanah meliputi: profil tanah, tekstur, struktur, konsistensi, kesuburan tanah. Sifat geografis lahan meliputi: kemiringan lahan, geomorfologi, kepekaan erosi, iklim, dsb. Yunus (2010) mendefinisikan nilai lahan sebagai pengukuran kemampuan lahan atas dasar ekonomis yang berkaitan dengan produktivitas lahan dan strategi ekonomi. Status lahan menjelaskan hak apa yang melekat pada lahan tersebut.

Berkaitan dengan karakteristik lahan yang terbatas, dinamika perkembangan kegiatan di kawasan perkotaan menimbulkan persaingan antar penggunaan lahan yang mengarah pada terjadinya perubahan penggunan lahan dengan intensitas yang semakin tinggi. Kota Palembang sebagai ibu kota provinsi Sumatera Selatan, tak luput dari dinamika pembangunan wilayah yang tampak pada perubahan morfologi kotanya. Kota Palembang mengalami perubahan cukup pesat dalam kurun waktu satu dasawarsa terakhir, dan kini menjadikan Kota Palembang sebagai pintu gerbang ekonomi di kawasan Sumatera. Pertumbuhan ekonomi lokal kota Palembang memiliki keunikan berupa strategi pengembangan dengan konsep ekonomi resiliensi yaiatu pola pengelompokkan (clustering) yang dijabarkan melalui penetapan kawasan strategis daerah.

Sebagai bentuk penataan ruang wilayah, pengembangan kawasan strategis kota/daerah merupakan perwilayahan fungsional yang dibentuk dengan tujuan untuk memadukan pembangunan infrastruktur wilayah dengan pengembangan kawasan strategis dan/atau antar kawasan strategis (Muta'ali, 2015). Pada tahun 2012 ditetapkan kawasan strategis di Kota Palembang, yang terdiri dari 7 (tujuh) kawasan strategis ekonomi dan 2 (dua) kawasan strategis budaya. Salah satu kawasan strategis ekonomi tersebut adalah Kasiba-Lisiba Talang Kelapa yang berada di Kecamatan Alang-Alang Lebar Kota Palembang. Penetapan kawasan strategis Kasiba-Lisiba selain dimaksudkan sebagai pusat permukiman yang mengakomodir tempat tinggal penduduk kota yang semakin meningkat juga berfungsi sebagai pusat pertumbuhan baru di pinggiran kota Palembang.
Kawasan strategis dipandang sebagai kawasan yang memiliki potensi sumberdaya ekonomi yang strategis yang ditetapkan untuk menyelenggarakan fungsi perekonomian yang ditujukan untuk melipatgandakan (multiplier) pertumbuhan ekonomi, serta mendorong peningkatan perekonomian, penciptaaan lapangan kerja, dan kesejahteraan masyarakat serta pemerataan perkembangan wilayah (Muta'ali, 2015). Sebagai kawasan strategis Kasiba-Lisiba dalam pembentukannya juga diharapkan dapat menjadi penggerak utama (prime mover) dalam perkembangan kota. Sektor permukiman sebagai penggerak utarma pembangunan belum disebutkan dalam konsep dan teori keunggulan komparatif yang mendasari pengembangan kawasan strategis, karena lebih menekankan pada keberadaan pusat-pusat ekonomi berupa industri dan perdagangan.

Sebagai suatu kebijakan keruangan Kasiba-Lisiba sebagai kawasan strategis merupakan kawasan yang dikembangkan dengan keunggulan komparatif berdasarkan pusat permukiman skala besar. Menurut Richardson dalam Lutfi (2007) sektor unggulan sebagai penggerak utama lebih mendasarkan pada sektor ekonomi penggerak (propulsive economic sector) dan industri andalan (leading industries).

\section{METODE PENELITIAN}

Penelitian ini menggunakan pendekatan deduktif kuantitatif dan kualitatif (mixed method). Data yang digunakan adalah data primer yang diperoleh dari kuesioner dan observasi langsung mengenai perkembangan kawasan, jenis, d jenis dan jumlah fasilitas pelayanan, penggunaan dan pemanfaata lahan, aksesibilitas dan jaringan jalan di Kasiba-Lisiba Talang Kelapa. Data sekunder dari instansi pemerintah dari Bappeda, BPN, dan BPS.

Variabel dalam penelitian mengunakan definisi karakteristik lahan dari Sadyohutomo (2016) dengan variabel operasional sebagai berikut (Tabel 1).

\section{Tabel 1. Variabel Penelitian}

\begin{tabular}{cll}
\hline No. & \multicolumn{1}{c}{ Variabel } & \multicolumn{1}{c}{ Sub Variabel } \\
\hline 1. & Penggunaan Lahan & Luas Lahan Terbangun \\
\hline 2. & Nilai Lahan & Harga Lahan \\
\cline { 3 - 3 } & & Jumlah Pemanfaatan Lahan \\
\hline 3. & Status Lahan & Perolehan Lahan \\
\cline { 3 - 3 } & & Status Lahan \\
\hline
\end{tabular}

Unit analisis dalam penelitian ini adalah lahan yang diwakili persil di kawasan strategis Kasiba-Lisiba Talang Kelapa Alang Alang Lebar Kota Palembang. Berdasarkan data sekunder dari KKP BPN Kota Palembang yang diunduh per tanggal 12 Oktober 2016, jumlah persil 
terpetakan yang berada di dalam area kawasan strategis Kasiba-Lisiba Kota Palembang sebanyak 9.807 persil. Sehingga jumlah tersebut menjadi jumlah populasi dari penelitian ini. Menggunakan tabel dari Arkin, H. dan Coltton., 1963, "Tables for Statisticians", Barner and Noble, New York, dengan confidence level 95\% dari total populasi sebanyak 9.807 maka jumlah sampel yang diambil sebanyak 199. Metode pemilihan sampel menggunakan simple random sampling yaitu suatu teknik dalam proses pengambilan sampel dengan cara seleksi acak/bebas. Sebaran populasi ditunjukkan pada (Gambar 1).

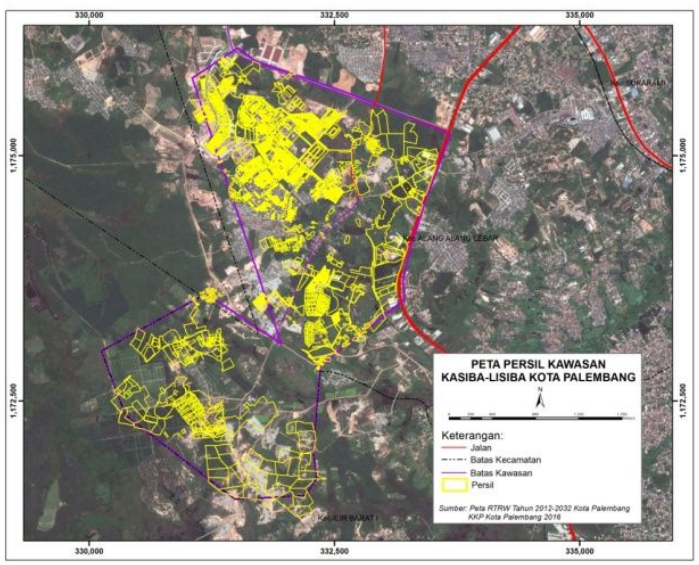

Gambar 1. Peta Sebaran Populasi Penelitian

Analisis data dalam penelitian ini disesuaikan dengan data yang digunakan dan tujuan yang akan dicapai. Analisis deskriptif digunakan untuk mendeskripsikan perubahan penggunaan lahan di kawasan dengan interpretasi citra, analisis before-after digunakan untuk menjawab pertanyaan perubahan harga lahan. Analisis Crosstab digunakan untuk menguji perubahan karakteristik lahan berupa perolehan lahan, status lahan, dan pemanfaatan lahan dari data kuesioner.

\section{HASIL DAN PEMBAHASAN}

Perubahan karakteristik lahan sebelum dan setelah penetapan kawasan strategis KasibaLisiba Kota Palembang, menekankan pada perubahan dari atribut-atribut yang terangkum dalam karakteristik lahan. Perubahan atribut lahan menjadi fenomena yang sering ditemui dengan adanya pembangunan wilayah yang berimbas pada peningkatan jumlah penduduk dan aktifitas diatasnya. Perubahan karakteristik lahan dalam penelitian ini menggunakan atribut lahan dari Sadyohutomo (2016) dengan menekankan pada luas lahan terbangun, harga lahan, perolehan lahan, status lahan, dan pemanfaatan lahan.

\section{Lahan Terbangun Sebelum dan Setelah Penetapan Kasiba-Lisiba}

Berdasarkan interprestasi citra menunjukkan terdapat perubahan lahan terbangun di Kawasan Kasiba-Lisiba Talang Kelapa. Perkembangan fisik kekotaan di KasibaLisiba Talang Kelapa cenderung berubah melalui perembetan konsentris penggunaan lahan terbangun, dengan pusat berada pada Perumnas Talang Kelapa. Seiring berjalannya waktu dengan meningkatnya jumlah penduduk akibat berbagai aspek terutama intervensi pembangunan di kawasan sebagai kawasan strategis cepat tumbuh, mengakibatkan meningkatnya kegiatan penduduk yang berdampak pada meningkatnya lahan terbangun dengan perubahan pengguaan lahan non urban menjadi penggunaan lahan urban.

Meningkatnya laju perubahan lahan terbangun setelah penetapan menunjukkan pesatnya perkembangan wilayah di kawasan tersebut, serta dapat dikatakan bahwa terdapat hubungan antara perubahan lahan dan penetapan kawasan strategis Kasiba-Lisiba Talang Kelapa. Perubahan penggunaan lahan dari lahan tak terbangun menjadi lahan terbangun didominasi perumahan dan fasilitas pendukungnya. Perkembangan lahan terbangun ditunjukkan pada (Gambar 2).

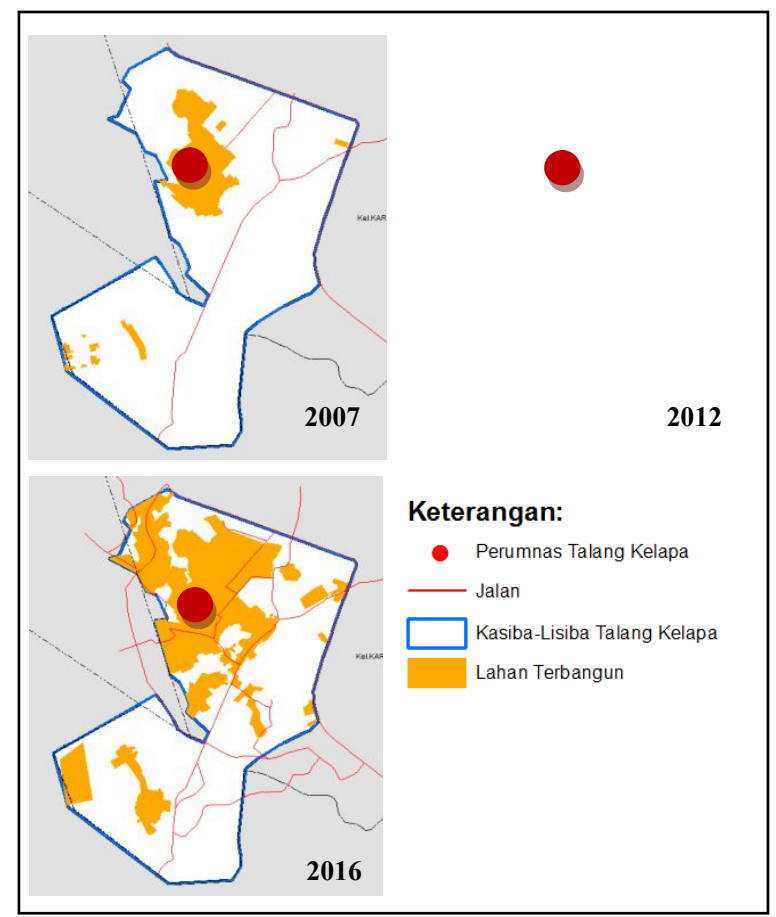

Gambar 2. Peta Perubahan Lahan Terbangun di Kasiba-Lisiba Talang KelapaTahun 2007-2016 
Luas lahan tak terbangun yang berubah menjadi lahan terbangun selama rentang 10 tahun sebesar 192,54 Ha, sehingga pada tahun 2016 luas lahan terbangun jumlahnya meningkat mencapai 31,49\% dari luas keseluruhan kawasan. Perbedaan perubahan lahan terbangun di KasibaLisiba Talang Kelapa antara sebelum dan setelah penetapan dapat dilihat dari laju perubahan lahan terbangun. Laju perubahan sebelum penetapan di kawasan sebesar $4,42 \%$ dan setelah penetapan meningkat cukup pesat menjadi $18,19 \%$ (Tabel 2).

Tabel 2. Luas Lahan Terbangun Sebelum dan Setelah Penetapan Kawasan

\begin{tabular}{|l|r|r|}
\hline & $\begin{array}{c}\text { Tahun 2007- } \\
\mathbf{2 0 1 2} \\
\text { (Sebelum } \\
\text { Penetapan) }\end{array}$ & $\begin{array}{c}\text { Tahun 2012- } \\
\mathbf{2 0 1 6} \\
\text { (Setelah } \\
\text { Penetapan) }\end{array}$ \\
\hline $\begin{array}{l}\text { Luas perubahan lahan tak } \\
\text { terbangun menjadi } \\
\text { terbangun }\end{array}$ & $38,33 \mathrm{Ha}$ & $154,21 \mathrm{Ha}$ \\
\hline $\begin{array}{l}\text { Persentase terhadap luas } \\
\text { kawasan }\end{array}$ & $4,52 \%$ & $18,19 \%$ \\
\hline
\end{tabular}

Penggunaan lahan terbangun akan berubah seiring dengan meningkatnya aktivitas manusia diatasnya yang sangat berkaitan dengan keberadaan sarana, prasarana dan utilitas lingkungan didalamnya. Sebagai suatu kawasan strategis kota, Kawasan Strategis Kasiba-Lisiba Talang Kelapa juga mendapat intervensi pemerintah agar kawasan tersebut lebih cepat tumbuh. Kasiba-Lisiba Talang Kelapa ditetapkan sebagai Sub Bagian Wilayah Perkotaan (Sub BWP) Kecamatan Alang Alang Lebar yang diprioritaskan penangannya. Di dalam RTRW Kota Palembang Tahun 2012-2032 tercantum dalam program perwujudan kawasan yang memiliki nilai strategis dari aspek ekonomi Kasiba-Lisiba.

\section{Perubahan Harga Lahan}

Gambaran sebaran harga lahan di KasibaLisiba menunjukkan pada tahun 2007 harga lahan relatif seragam, rentang harga antar lokasi dalam kawasan relatif kecil, harga meningkat pada lokasi-lokasi yang mendekati koridor jalan. Pada tahun 2012 terdapat perubahan harga lahan pada kawasan sebelah utara dengan peningkatan yang cukup besar, tumbuhnya perumahan elite dengan ketersediaan fasilitas yang mumpuni menjadi faktor harga jual lahan menjadi tinggi. Rentang harga lahan antara harga terendah dan tertinggi cukup besar di kawasan, lokasi di sebelah selatan memiliki harga relatif rendah dan semakin ke utara semakin tinggi. Terdapat lokasi-lokasi yang mengalami lonjakan harga lahan akibat proses perolehan atau pembebasan. Pada tahun 2016 setelah penetapan kawasan rentang harga lahan hampir sama seperti pada tahun 2012, hal ini disebabkan banyaknya lahan yang telah berubah dari lahan tak terbangun menjadi lahan terbangun yang memiliki keuntungan yang diperoleh dari investasi (capital gain) lebih besar.

Namun di beberapa lokasi tertentu kenaikan harga lahan tidak terlalu tinggi/drastis. Lokasi tersebut antara lain di sebelah selatan perumnas Talang Kelapa yang dibangun perumahan-perumahan baru dengan didominasi perumahan yang bersubsidi, dan di bagian selatan yang masih masih didominasi rawa dan belukar.Terdapat indikasi harga lahan meningkat dari tahun ke tahun, dengan harga yang lebih tinggi berada di sekitar koridor yang memiliki aksesibilitas lebih baik (Gambar 3).

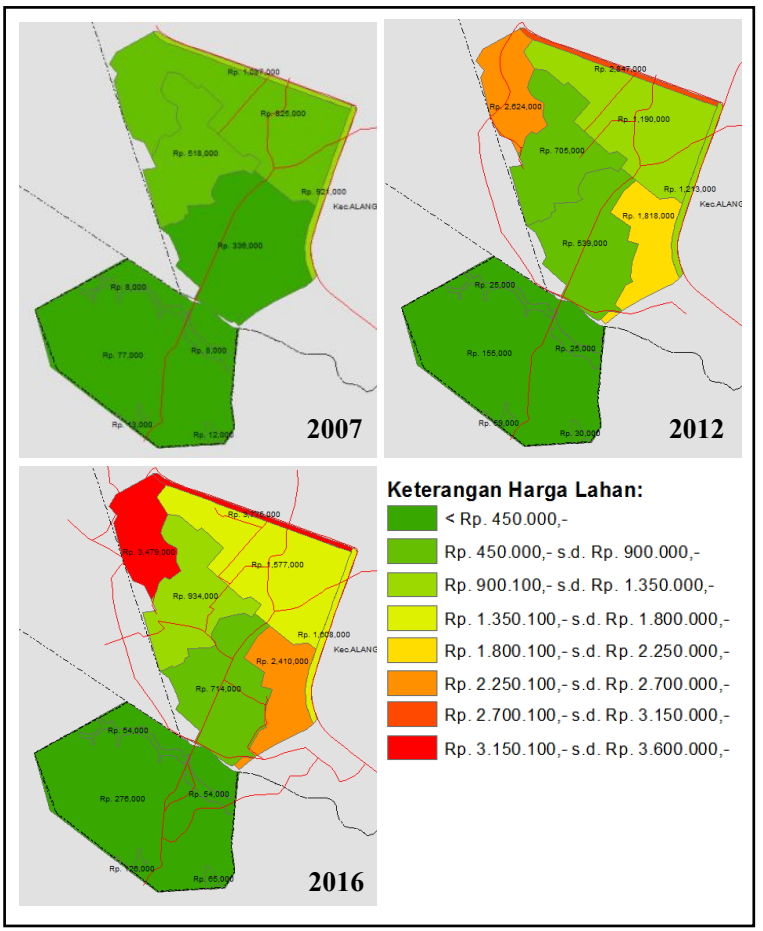

Gambar 3. Peta Perubahan Lahan Terbangun di Kasiba-Lisiba Talang KelapaTahun 2007-2016

Untuk mengetahui apakah terdapat perbedaan laju perubahan harga lahan sebelum dan setelah penetapan Kasiba-Lisiba Talang Kelapa digunakan pengujian statistik dua sampel berkaitan (Wilcoxon Signed Rank Test) dengan tingkat kepercayaan sebesar 95\%. Hasil yang diperoleh menunjukkan nilai sig sebesar 0,000, sehingga dapat diartikan terdapat perubahan laju kenaikan harga lahan yang cukup siginifikan antara sebelum dan setelah penetapan KasibaLisiba Talang Kelapa. Jika dilihat dari angka negative ranks yang berjumlah lebih sedikit dari positive ranks menunjukkan bahwa laju kenaikan harga lahan setelah penetapan lebih besar daripada sebelum penetapan (Tabel 3). 
Tabel 3. Hasil Uji Statistik Perubahan Harga Lahan

\begin{tabular}{|c|c|c|c|c|}
\hline & & $\mathrm{N}$ & $\begin{array}{l}\text { Mean } \\
\text { Rank }\end{array}$ & $\begin{array}{c}\text { Sum of } \\
\text { Ranks }\end{array}$ \\
\hline \multirow[t]{4}{*}{$\begin{array}{l}\text { AFTER } \\
\text { BEFORE }\end{array}$} & $\begin{array}{l}\text { - Negative } \\
\text { Ranks }\end{array}$ & & 15.00 & 45.00 \\
\hline & $\begin{array}{l}\text { Positive } \\
\text { Ranks }\end{array}$ & $28^{\mathrm{b}}$ & \multirow[t]{3}{*}{16.11} & \multirow[t]{3}{*}{451.00} \\
\hline & Ties & $0^{\mathrm{c}}$ & & \\
\hline & Total & 31 & & \\
\hline & & AFTER & BEFORE & \\
\hline Z & & & $-3.979^{b}$ & \\
\hline Asymp. & (2-tailed) & & .000 & \\
\hline
\end{tabular}

Meningkatnya harga lahan di KasibaLisiba Talang Kelapa setelah penetapan dikarenakan adanya penguasaan lahan oleh beberapa pihak. Pihak-pihak ini adalah para pengembang, investor serta kumpulan pemilik modal yang membeli lahan dalam skala luas kemudian diolah dan dijual kembali. Pengembang dan investor yang melakukan penguasaan lahan di kawasan relatif cukup banyak sehingga berpengaruh dalam pasar lahan di kawasan.

Meningkatnya luas lahan terbangun khususnya permukiman, bertambahnya sarana dan prasarana pendukung, serta meningkatnya aksesibilitas setelah penetapan kawasan menjadikan daya tarik lokasi semakin besar dalam pasar lahan di Kota Palembang. Sehingga berdampak terdapat peningkatan permintaan lahan di kawasan. Sesuai dengan hukum ekonomi, kelangkaan sumber daya sangat menentukan harga komoditi. Seperti yang dijelaskan Sadyohutomo (2016) bahwa prinsip peningkatan harga karena peningkatan permintaan sebenarnya berlaku untuk umum semua barang, akan tetapi untuk lahan menunjukkan kekhususan. Keunikan lahan yang dimaksud adalah karena sifat kelangkaannya (luasnya tetap, sedangkan permintaan selalu bertambah) dan lahan sebagai aset tidak bergerak. Posisi lokasi lahan yang tidak bisa berpindah menyebabkan harga lahan dipengaruhi oleh nilai lokasi.

\section{Cara Perolehan Lahan Sebelum dan Setelah Penetapan Kasiba-Lisiba}

Cara perolehan lahan dapat diartikan sebagai setiap kegiatan untuk mendapatkan tanah melalui pemindahan hak atas tanah dengan pemberian ganti kerugian kepada yang berhak. Cara perolehan lahan dapat pula digunakan untuk melihat nilai sosial lahan, yaitu seberapa besar keterikatan pemilik dan lahan yang dimiliki.
Berdasarkan uji tabulasi silang (Crosstab) dari sampel kuesioner diperoleh nilai signifikansi sebesar 0,13 . Nilai ini lebih besar dari $\alpha(0,05)$, sehingga Ho diterima. Apabila dilihat dari nilai pearson chi-square ( $\chi 2$ hitung) sebesar 4,079 lebih kecil dari tabel $\chi_{0,05}(2)=5,99$. Dapat diartikan bahwa perolehan lahan tidak memiliki hubungan dengan waktu perolehan lahan. Antara sebelum dan setelah penetapan, perolehan lahan dilakukan melalui mekanisme yang sama (Tabel 4).

Tabel 4. Hasil Uji Statistik Cara Perolehan Lahan dan Tahun Perolehan

\begin{tabular}{|c|c|c|c|}
\hline & Value & df & $\begin{array}{c}\text { Asymptotic } \\
\text { Significance } \\
\text { (2-sided) }\end{array}$ \\
\hline Pearson Chi-Square & $4.079^{\mathrm{a}}$ & 2 & .130 \\
\hline Likelihood Ratio & 4.337 & 2 & .114 \\
\hline Linear-by-Linear & 543 & 1 & 111 \\
\hline Association & & & \\
\hline $\mathrm{N}$ of Valid Cases & 199 & & \\
\hline
\end{tabular}

Jika dilihat dari persentase perolehan lahannya, sebagaian besar lahan di Kasiba-Lisiba Talang Kelapa baik sebelum maupun setelah penetapan diperoleh dengan mekanisme jual-beli. Sedangkan perolehan lahan dengan cara waris atau hibah relatif sedikit baik sebelum maupun setelah penetapan. Berdasarkan frekuesinya diketahui bahwa jumlah perolehan lahan dengan cara waris mengalami penurunan setelah penetapan kawasan. Hal ini dikarenakan mayoritas pemilik lahan merupakan keluarga pendatang yang baru tinggal di perumahanperumahan yang dibangun setelah penetapan, faktor usia dan lama tinggal di kawasan yang masih belum lama secara tidak langsung berpengaruh pada proses pewarisan. Sedangkan jumlah perolehan melalui hibah cenderung stabil baik sebelum maupun setelah penetapan, dan tidak terpengaruh adanya penetapan KasibaLisiba (Tabel 5).

Tabel 5. Frekuensi Perolehan Lahan

\begin{tabular}{|l|r|r|}
\hline & \multicolumn{2}{|c|}{ Tahun 2} \\
\cline { 2 - 3 } & & $\begin{array}{c}\text { Setelah } \\
\text { Tahun } \\
\text { Sebelum } \\
\text { Tahun 2012 }\end{array}$ \\
2012 \\
\hline Waris & 14 & 4 \\
Expected Count & 10.1 & 7.9 \\
Persentase (\%) & $12.5 \%$ & $4.6 \%$ \\
\hline Hibah & 4 & 5 \\
Expected Count & 5.1 & 3.9 \\
Persentase (\%) & $3.6 \%$ & $5.7 \%$ \\
\hline Jual-Beli & 94 & 78 \\
Expected Count & 96.8 & 75.2 \\
Persentase (\%) & $83.9 \%$ & $89.7 \%$ \\
\hline Total & 112 & 87 \\
Expected Count & 112.0 & 87.0 \\
Persentase (\%) & $100.0 \%$ & $100.0 \%$ \\
\hline
\end{tabular}


Berdasarkan data-data tersebut dapat disimpulkan bahwa penetapan Kasiba-Lisiba di Talang Kelapa tidak memiliki hubungan pada mekanisme perolehan lahan. Baik sebelum maupun setelah penetapan kawasan, perolehan lahan didominasi dengan mekanisme jual-beli. Lahan secara bebas diperjual-belikan sejalan dengan tuntutan kebutuhan dan faktor mekanisme supply-demand pasar tanah (adanya permintaan dan penawaran). Tidak terdapat keterkaitan yang cukup kuat antara pemilik lahan dan lahan seperti halnya keterkaitan pada tanah-tanah milik adat.

\section{Status Lahan Sebelum dan Setelah Penetapan Kasiba-Lisiba}

Komposisi perubahan status hak atas tanah di Kasiba-Lisiba Talang Kelapa antara sebelum dan setelah menunjukkan status hak atas tanah dari HGB menjadi HM meningkat sebanyak 3\% pada tahun setelah penetapan, yaitu dari 2.669 permohonan menjadi 4.041 permohonan. Sebelum penetapan, lahan banyak dibeli oleh pemohon dari Perumnas dengan status HGB. Untuk peningkatan hak, pemilik lahan perlu biaya ekstra, ditambah pengurusan tidak dibantu oleh pihak pengembang, sehingga terdapat kecenderungan kurangnya minat pemilik untuk meningkatkan status haknya. Sedangkan setelah penetapan terdapat kemudahan dalam pengurusan perubahan status HGB menjadi Hak Milik pada lahan yang dibeli sebagai salah satu strategi penjualan (marketing) oleh pengembang perumahan sehingga jumlah perubahannya cenderung meningkat. Jumlah permohonan perubahan status lahan ditunjukkan pada (Gambar 4).

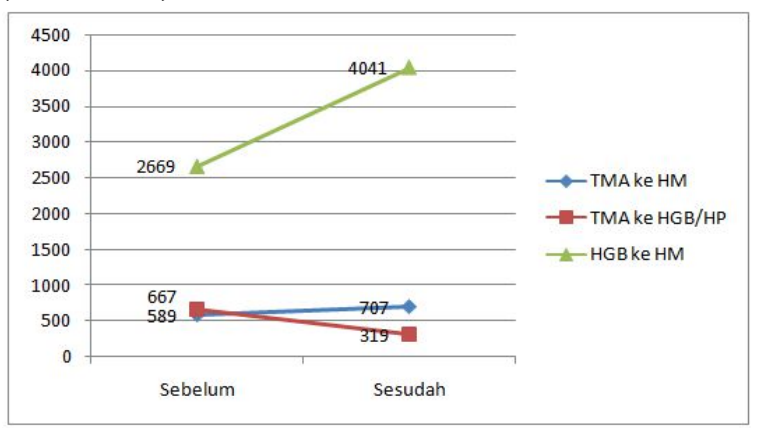

Gambar 4. Grafik Jumlah Permohonan Hak Atas Tanah di Kasiba-Lisiba Talang Kelapa Sebelum dan Setelah Penetapan

Untuk memperkuat adanya hubungan antara status lahan dengan penetapan KasibaLisiba yang diasumsikan dengan tahun perolehan digunakan uji tabulasi silang data kuesioner. Perolehan nilai signifikansi sebesar 0,000 lebih kecil dari $\alpha(0,05)$, sehingga Ho ditolak. Apabila dilihat dari nilai pearson chi-square ( $\chi^{2}$ hitung) sebesar 59,648 lebih besar dari tabel $\chi 2_{0,05}$ (2) $=5,99$. Berdasarkan hasil uji statistik tersebut dapat diartikan bahwa terdapat hubungan antara status lahan dengan tahun perolehan. Antara sebelum dan setelah penetapan kawasan mengalami perbedaan status lahan dengan setelah penetapan status lahan lebih banyak berupa Hak Milik (Tabel 6).

Tabel 6. Hasil Uji Statistik Status Lahan dan Tahun Perolehan

\begin{tabular}{|c|c|c|c|}
\hline & Value & $\mathrm{df}$ & $\begin{array}{l}\text { Asymptotic } \\
\text { Significance } \\
\text { (2-sided) }\end{array}$ \\
\hline $\begin{array}{l}\text { Pearson Chi-Square } \\
\text { Likelihood Ratio } \\
\text { Linear-by-Linear } \\
\text { Association } \\
\mathrm{N} \text { of Valid Cases }\end{array}$ & $\begin{array}{r}59.648^{\mathrm{a}} \\
65.182 \\
59.121 \\
199\end{array}$ & $\begin{array}{l}2 \\
2 \\
1\end{array}$ & $\begin{array}{r}.000 \\
.000 \\
.000\end{array}$ \\
\hline
\end{tabular}

Penetapan Kasiba-Lisiba Talang Kelapa memiliki hubungan dengan status lahan secara signifikan. Terdapat kecenderungan status hak atas tanah dengan status Hak Milik yang lebih banyak setelah penetapan dan dapat dikatakan bahwa terdapat peningkatan status lahan di kawasan. Adanya program pengurusan perubahan status lahan baik dari pihak swasta (pengembang/developer) mupun pihak pemerintah mejadi pemicu perubahan status lahan di Kasiba-Lisiba Talang Kelapa.

\section{Pemanfaatan Lahan Sebelum dan Setelah Penetapan Kasiba-Lisiba}

Pemanfaatan lahan merupakan gambaran kegiatan manusia yang meyatu dengan penggunaan lahan pokoknya, dalam penelitian ini dikelompokkan menjadi: rumah untuk tempat tinggal, rumah sekaligus untuk kegiatan perdagangan, rumah untuk kegiatan jasa, dan rumah dengan kebun untuk pertanian. Nilai lahan sebagai bagian dari karakteristik lahan dapat diukur berdasar kemampuan lahan yang berkaitan dengan penggunan dan pemanfaaan lahan (Kok dkk, 2011). Dimana semakin banyak pemanfaatan di suatu lahan maka nilai lahan tersebut akan semakin tinggi.

Menggunakan uji tabulasi silang antara jumlah pemanfaatan dan tahun perolehan lahan dihasilkan nilai signifikansi sebesar 0,035 . Nilai ini lebih kecil dari $\alpha(0,05)$, sehingga Ho ditolak. Dilihat dari nilai pearson chi-square ( $\chi^{2}$ hitung) sebesar 4,429 lebih besar dari tabel $\chi 2_{0,05(1)}=3,84$. Dengan demikian dapat diartikan bahwa terdapat hubungan antara jumlah pemanfaatan lahan dengan tahun perolehan lahan. Terdapat perbedaan jumlah pemanfaatan antara sebelum dan setelah penetapan, dengan kecenderungan 
setelah penetapan lebih ke arah 1 pemanfaatan (Tabel 7).

Tabel 7. Hasil Uji Statistik Pemanfaatan Lahan dan Tahun Perolehan

\begin{tabular}{|l|r|r|r|}
\hline & & & \multicolumn{2}{|c|}{$\begin{array}{c}\text { Asymptotic } \\
\text { Significance (2- } \\
\text { sided) }\end{array}$} \\
\hline Pearson Chi-Square & \multicolumn{1}{|c|}{$4.429^{\mathrm{a}}$} & 1 & .035 \\
Continuity & 3.522 & 1 & .061 \\
Correction $^{\mathrm{b}}$ & 4.723 & 1 & .030 \\
Likelihood Ratio & & & \\
Fisher's Exact Test & & 1 & .036 \\
Linear-by-Linear & 4.407 & 1 & \\
Association & 199 & & \\
N of Valid Cases & & \\
\hline
\end{tabular}

Sebelum penetapan, sejumlah lahan di Kasiba-Lisiba selain dipergunakan sebagai tempat tinggal sekaligus digunakan untuk kegiatan lainnya untuk memperoleh nilai tambah secara ekonomi, seperti bengkel, warung, toko kelontong, dan kegiatan jasa (Notaris/PPAT, binatu, warnet). Setelah penetapan, terdapat kecenderungan sebagian besar lahan dimanfaatkan sebagai tempat tinggal saja. Nilai tambah ekonomi lahan juga menunjukkan memiliki peluang yang lebih rendah di lokasi perumahan kelas menengah. Lahan terbangun berupa perumahan difungsikan hanya sebagai rumah tinggal, dan bahkan beberapa lahan dibeli hanya sebatas investasi dan belum dimanfaatkan untuk rumah tinggal atau kegiatan lain (Gambar $5)$.

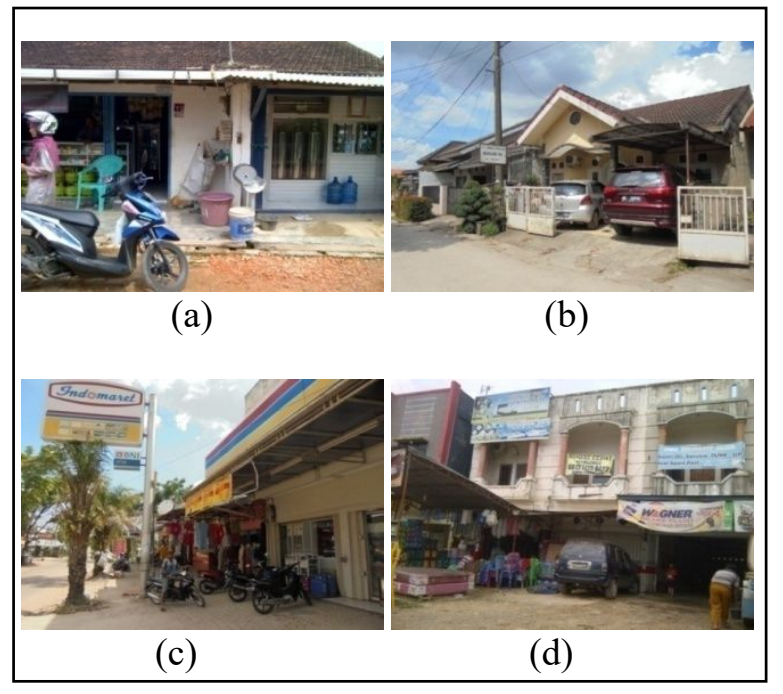

Gambar 4. Pemanfaatan Lahan di Kasiba-Lisiba Talang Kelapa Sebelum dan Setelah Penetapan

Keterangan:

(a). Pemanfaatan rumah tinggal dan perdagangan sebelum penetapan.

(b). Pemanfaatan rumah tinggan dan jasa sebelum penetapan

(c). Pemanfaatan kegiatan perdagangan setelah penetapan (d). Pemanfaatan kegiatan perdangan seteleh penetapan

\section{KESIMPULAN}

Penetapan Kasiba-Lisiba Talang Kelapa sebagai salah satu kawasan strategis daerah dimaksudkan sebagai kawasan cepat tumbuh sebagai upaya pemerataan pembangunan di Kota Palembang. Selain tujuan tersebut, penyelenggaraan Kasiba-Lisiba juga dimaksudkan untuk memenuhi kebutuhan perumahan dan permukiman, serta mengendalikan agar tidak timbul perumahan (kampung) kumuh baru akibat tidak memenuhi persyaratan alokasi lahan untuk prasarana, sarana, dan utilitas lingkungan. Kasiba-Lisiba juga merupakan bentuk campur tangan pemerintah dalam penyeimbangan pasar anah dengan penyediaan tanah kaveling untuk perumahan.

Berdasarkan lima variabel karakteristik lahan, terdapat empat variabel yang mengalami perubahan dan satu atribut lahan yang tidak mengalami perubahan antara sebelum dan setelah penetapan Kasiba-Lisiba. Luas lahan terbangun meningkat dari 38,33 Ha pada periode sebelum penetapan meningkat menjadi 154,21 Ha setelah penetapan. Berdasarkan uji statistik menunjukkan terdapat hubungan antara harga lahan, status lahan, dan pemanfaatan lahan dengan tahun/dua periode waktu. Sedangkan perolehan lahan di lokasi tidak memiliki hubungan dengan tahun perolehan.

Hal tersebut menunjukkan bahwa dengan ditetapkannya Kasiba-Lisiba Talang Kelapa sebagai kawasan cepat tumbuh terdapat pengaruh atau hubungan yang siginifikan terhadap perubahan karakteristik lahan di kawasan pada tahun 2012.

Dalam pengembangan kawasan strategis, pemerintah Kota Palembang selain mendorong perkembangannya dengan berbagai kebijakan dan program, juga perlu melakukan kontrol. Perubahan karakteristik lahan di kawasan yang tidak terkontrol khususnya dalam kenaikan harga lahan dapat menyebabkan berkurangnya akses terhadap lahan pada Masyarakat Berpendapatan Rendah. Selain itu juga perlu kontrol peningkatan luas lahan terbangun agar tidak melampaui daya dukung wilayah sesuai yang direncanakan.

\section{DAFTAR PUSTAKA}

Giyarsih, S. R. (2012). Dampak Transformasi Wilayah Terhadap Kondisi Kultural Penduduk (Tinjuan Perspektif Geografis). Forum Geografi, 120-131. 
Kok, N., Eicholtz, P., \& Quigley, J. M. (2011). Economic Geography, Jobs and Regulations: The Value of Land and Housing. http://urbanpolicy. berkely.edu/pdf/KMQ_Geography_JMQO 211811.pdf. Diunduh tanggal 15 Februari 2017.

Lutfi. (2007). Pengembangan Wilayah Sebagai Konsep Kota Baru. http://jurnal.untad.ac.id/jurnal/index. $\mathrm{php/SMARTEK/article/view/451.}$ Diunduh Tanggal 4 Maret 2018.

Muta'ali, L. (2015). Pengembangan Kawasan Strategis Ekonomi. Yogyakarta: Badan Penerbit Fakultas Geografi Universitas Gadjah Mada.

Pemerintah Kota Palembang (2012). Peraturan Darah Kota Palembang Nomor 15 Tahun 2012 tentang Rencana Tata Ruang Wilayah (RTRW) Kota Palembang Tahun 2012-2032. Bappeda Kota Palembang.

Sadyohutomo, M. (2016). Tata Guna Tanah dan Penyerasian Tata Ruang. Yogyakarta: Pustaka Pelajar.

Yunus, H. S. (1994). Teori dan Model Struktur Keruangan Kota. Yogyakarta: Fakultas Geografi, Universitas Gadjah Mada. 